\title{
Metabotropic glutamate receptor 5 shows different patterns of localization within the parallel visual pathways in macaque and squirrel monkeys
}

This article was published in the following Dove Press journal:

Eye and Brain

24 September 2014

Number of times this article has been viewed

\author{
Yuri Shostak ${ }^{1,5}$ \\ Ashley Wenger ${ }^{4}$ \\ Julia Mavity-Hudson' \\ Vivien A Casagrande ${ }^{1-3}$ \\ 'Department of Cell and \\ Developmental Biology, ${ }^{2}$ Department \\ of Psychology, ${ }^{3}$ Department of \\ Ophthalmology and Visual Sciences, \\ ${ }^{4}$ Undergraduate Neuroscience \\ Program, Vanderbilt University, \\ Nashville, TN, USA; ${ }^{5}$ Foreign Trade \\ Unitary Enterprise, Minsk, Belarus
}

\begin{abstract}
Glutamate is used as an excitatory neurotransmitter by the koniocellular $(\mathrm{K})$, magnocellular $(\mathrm{M})$, and parvocellular $(\mathrm{P})$ pathways to transfer signals from the primate lateral geniculate nucleus (LGN) to primary visual cortex (V1). Glutamate acts through both fast ionotropic receptors, which appear to carry the main sensory message, and slower, modulatory metabotropic receptors (mGluRs). In this study, we asked whether mGluR5 relates in distinct ways to the K, M, and P LGN axons in V1. To answer this question, we used light microscopic immunocytochemistry and preembedding electron microscopic immunogold labeling to determine the localization of mGluR5 within the layers of V1 in relation to the $\mathrm{K}$, $\mathrm{M}$, and $\mathrm{P}$ pathways in macaque and squirrel monkeys. These pathways were labeled separately via wheat germ agglutinin-horseradish peroxidase (WGA-HRP) injections targeting the LGN layers. mGluR5 is of interest because it: 1) has been shown to be expressed in the thalamic input layers; 2) appears to be responsible for some types of oscillatory firing, which could be important in the binding of visual features; and 3) has been associated with a number of sensory-motor gating-related pathologies, including schizophrenia and autism. Our results demonstrated the presence of mGluR5 in the neuropil of all V1 layers. This protein was lowest in IVC $\alpha$ (M input) and the infragranular layers. In layer IVC, mGluR5 also was found postsynaptic to about $30 \%$ of labeled axons, but the distribution was uneven, such that postsynaptic mGluR5 label tended to occur opposite smaller (presumed P), and not larger (presumed M) axon terminals. Only in the K pathway in layer IIIB, however, was mGluR5 always found in the axon terminals themselves. The presence of mGluR5 in $\mathrm{K}$ axons and not in $\mathrm{M}$ and $\mathrm{P}$ axons, and the presence of mGluR5 postsynaptic mainly to smaller $\mathrm{P}$ and not larger M axons suggest that the response to the release of glutamate is modulated in distinct ways within and between the parallel visual pathways of primates.
\end{abstract}

Keywords: electron microscopy, immunocytochemistry, koniocellular, magnocellular, parvocellular, visual cortex

\section{Introduction}

The primary visual cortex (V1) of primates receives its main excitatory drive, defined as carrying the main sensory message, ${ }^{1}$ from the dorsal thalamic visual relay nucleus, the lateral geniculate nucleus (LGN). The LGN signals arrive via three main, largely parallel, pathways: the koniocellular $(\mathrm{K})$; magnocellular $(\mathrm{M})$; and parvocellular $(\mathrm{P})$ pathways. $^{2-4}$

These pathways send their axons to synapse in separate V1 layers with the M and P pathways primarily terminating within the upper and lower tiers of layer IVC (IV),
Correspondence: Vivien A Casagrande Department of Cell and Developmenta Biology, Vanderbilt University Medica School, U32 I 8 Learned Lab, 465 2Ist Avenue South, Nashville,

TN 37232-8240, USA

Tel +l 6153434538

Fax +I 6159365673

Email vivien.casagrande@vanderbilt.edu 
respectively, and the $\mathrm{K}$ pathway terminating within the cytochrome oxidase (CO)-rich blobs centered in layer III (IIIB $\alpha$ ), as well as in layer IVA (IIIB $\beta$ ), and also in layer I (Figure 1). Here, we provide layer designations for primates using both the more commonly used nomenclature of Brodmann, ${ }^{5}$ as well as the nomenclature more appropriate for across species and across cortical area comparisons (in parentheses). The latter layer designations were originally suggested

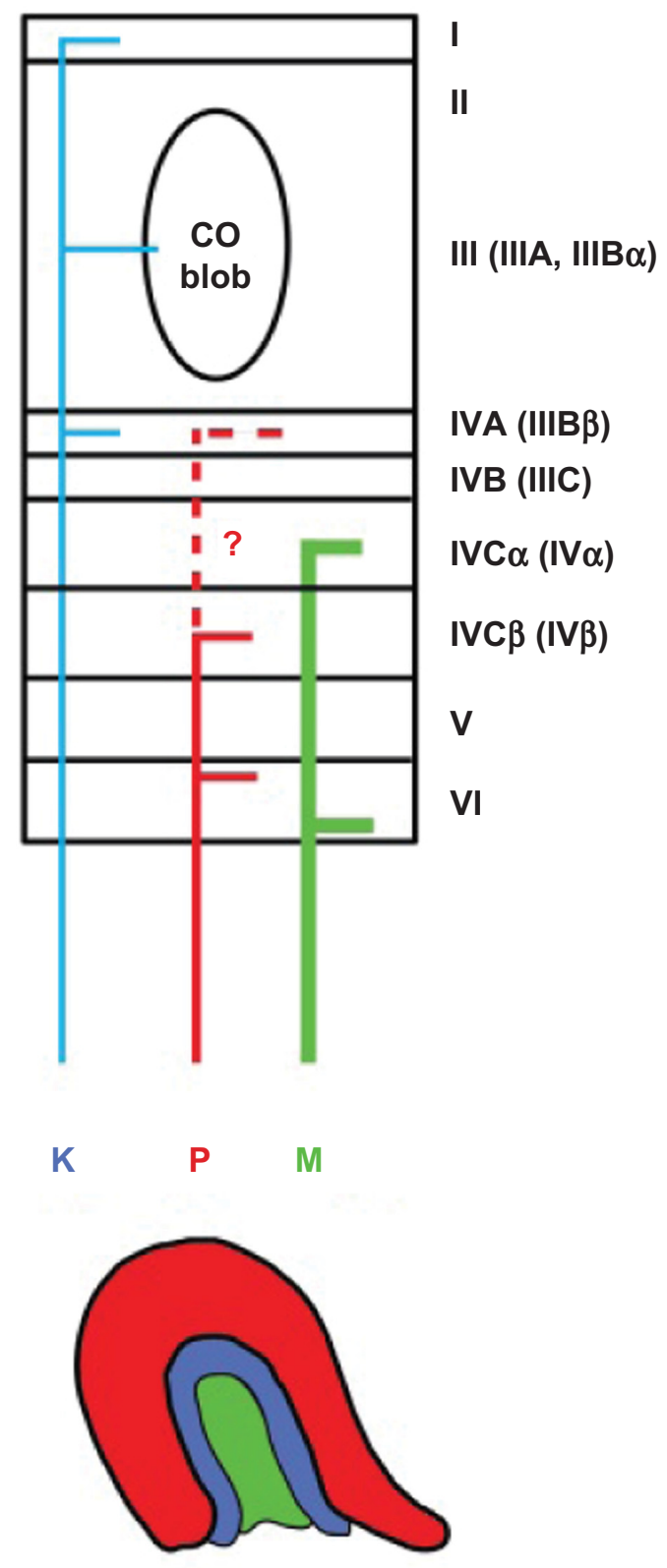

Figure I Schematic diagram of the koniocellular (K, blue), parvocellular ( $P$, red), and magnocellular ( $M$, green) pathways from LGN to $\mathrm{VI}$ in simian primates.

Notes: K LGN cells can send axons to one or more of the superficial layers (I, III [IIIB $\alpha$ ] or IVA [IIIB $\beta]$ ). P LGN cells can send axons to IVC $\beta$ (IV $\beta$ ) and VI and possibly IVA (IIIB $\beta$ ), or only to IVC $\beta$ (IV $\beta)$. M LGN cells send axons to IVC $\alpha$ (IV $\alpha$ ) and VI. Roman numerals represent cortical layers.

Abbreviations: LGN, lateral geniculate nucleus; VI, primary visual cortex; CO, cytochrome oxidase. by Hässler; ${ }^{6}$ see also Casagrande and $\mathrm{Kaas}^{3}$ for a review of the different naming systems and their rationales.

Although it is clear that each of the pathways from LGN to V1 performs a specialized function or functions as reviewed in Casagrande and Ichida, ${ }^{7}$ these pathways share a great deal in common at the neurochemical and ultrastructural levels. ${ }^{8}$ It has been suggested that glutamate is the predominant excitatory neurotransmitter used by all three pathways to transfer signals from the LGN to visual cortical cells; ${ }^{9,10}$ see also Morrison et al. ${ }^{11}$

Within V1, the microcircuitry of each of these pathways is also similar, with each pathway ending principally on the dendritic spines of neurons containing glutamate. . $^{8,9,12}$ Glutamate, however, can signal through a large number of receptors; for review, see Conn et al ${ }^{13}$ and Platt. ${ }^{14}$ These receptors belong to two principal classes - ionotropic and metabotropic. Previous studies have argued that pathways that carry the main message signal via ionotropic glutamate receptors (originally called driving pathways and currently referred to as class I pathways) while pathways that simply modulate the main message signal via metabotropic or modulatory receptors (referred to as class II pathways). ${ }^{1,15}$ Further, Jones ${ }^{16}$ proposed that thalamic inputs that end above layer IVC (IV), especially those pathways that end in layer I and whose thalamic cell bodies contain the calcium-binding protein calbindin, such as $\mathrm{K}$ axons, ${ }^{17}$ are distinct from those with axons ending in layer IVC proper, which in primate LGN contain the calcium-binding protein parvalbumin. Jones ${ }^{16}$ argued that axons ending in layer IVC (IV) form a main "core" pathway while axons ending superficially from thalamus form the "matrix". From the proposed wider distribution of matrix axons, Jones ${ }^{16}$ argued that while the core provides topographically precise sensory messages, axons forming the matrix might provide a means of binding messages together. Regardless, it is clear that the type of glutamate receptors utilized by the different LGN pathways can offer insight into potential functional differences between pathways. Therefore, a primary goal of this study was to examine the distribution of one important type of metabotropic glutamate receptor, mGluR5, in relation to the LGN input from the three major pathways to V1.

Ionotropic glutamate receptors are ligand-gated ion channels that generate fast excitatory postsynaptic potentials (EPSPs). They have been found ubiquitously within all layers of V1 in several species. ${ }^{18-23}$ Metabotropic glutamate receptors act instead through G-proteins, which can mediate both excitatory and inhibitory changes in activity over longer time courses by the activation of a number of intracellular 
metabolic pathways. ${ }^{13}$ The eight identified metabotropic glutamate receptors that have been cloned to date belong within three families. ${ }^{13,24-26}$ The members of these families have been shown to be distributed differently within the layers of cat visual cortex. ${ }^{20,21}$ Of these mGluRs, mGluR5 was originally of special interest to us for several reasons.

First, mGluR5 was found to be heaviest within the LGN input layers of V1 in the cat. ${ }^{21}$ It also was found to be densely distributed within other visual targets, such as the superior colliculus, in several species. ${ }^{27}$ Second, mGluR5 has been shown to be regulated developmentally in relation to the thalamocortical pathways, both in the visual system and the somatosensory system. ${ }^{21,28}$ For example, mGluR5 knockout mice show abnormalities in pattern formation within the entire somatosensory pathway, including segregation of thalamocortical axons and formation of barrels in cortex. ${ }^{29}$ In the visual system, mGluR5 also shows cortical changes in distribution in relation to total visual deprivation (dark-rearing) in the cat. ${ }^{30}$ Third, mGluR5 has been shown to be responsible for calcium waves that result in oscillatory firing behavior in several systems. ${ }^{31}$ Such oscillatory behavior has been seen in the visual cortex, and it has been proposed to be potentially important in the binding of visual features. ${ }^{32}$ Oscillatory behavior has been uniquely identified in K LGN cells in marmosets as well. ${ }^{33}$ Finally, the dysfunction of mGluR 5 has been implicated in a large number of neural disorders, ${ }^{34,35}$ including but not limited to fragile $\mathrm{X}$ syndrome, ${ }^{36}$ Alzheimer's disease, ${ }^{37}$ schizophrenia, ${ }^{38}$ attentiondeficit/hyperactivity disorder (ADHD) ${ }^{39}$ and autism. ${ }^{40}$ Thus, the primary objective of this study was to compare the distribution of mGluR5 in V1 at the light microscopic (LM) and ultrastructural, electron microscopic (EM) levels in relation to $\mathrm{K}, \mathrm{M}$, and $\mathrm{P}$ LGN axons in primates to determine if differences exist in the distribution of this modulatory receptor.

\section{Materials and methods Animals}

For this study, we used two adult squirrel monkeys (Saimiri sciureus) and six adult macaque monkeys (Macaca mulatta and Macaca radiata). Squirrel monkeys are New World monkeys, and macaques are Old World monkeys. All of the animals were cared for according to the National Institutes of Health's Guide for the Care and Use of Laboratory Animals, 1996 and the guidelines of the Vanderbilt University Animal Care and Use Committee under approved protocols.

\section{LGN axon labeling}

Details of the surgery were similar to those described previously. ${ }^{9,12,41-43}$ Briefly, prior to surgery, atropine sulfate
$(0.1 \mathrm{mg} / \mathrm{kg})$ was given to inhibit salivation. To inject tracer into the LGN $\mathrm{K}$ layers, the monkeys were intubated and deeply anesthetized with isoflurane $(3 \%-4 \%)$ in oxygen and maintained with the same gas mixture at $1 \%-2 \%$ during the surgery. All surgical procedures were carried out under sterile conditions while the animals were deeply anesthetized. Heart and respiration rates were continuously monitored and reflexes tested periodically. Animals were kept warm with a water-circulating heating pad throughout the surgery. Once deeply anesthetized, the monkeys were secured in a stereotaxic apparatus. Their skulls were exposed, craniotomies were performed, and dural flaps were elevated.

For the squirrel monkeys, the craniotomy over LGN was centered on the Horsley-Clarke coordinates of anterior $4.5 \mathrm{~mm}$ and lateral $8.0 \mathrm{~mm}$. For the macaque monkeys, the LGN craniotomy was centered on the Horsley-Clarke coordinates of anterior 7.0 $\mathrm{mm}$ and lateral $12.5 \mathrm{~mm}$. For the identification of the LGN layers - once the correct dorsal ventral position was established - the responses evoked by a flashing light were recorded extracellularly through a tungsten electrode (5.0 M $\Omega$, FHC Inc., Bowdoinham, ME, USA). When the K3 layer of LGN was identified on the basis of changes in eye dominance and levels of overall spontaneous activity, the electrode was removed and a glass pipette $(20-30 \mu \mathrm{m}$ inner tip diameter; [Drummond Scientific Company, Broomall, PA, USA]), filled with $1 \%$ wheat germ agglutinin conjugated to horseradish peroxidase (WGA-HRP; Sigma-Aldrich, St Louis, $\mathrm{MO}, \mathrm{USA}$ ) in saline was inserted at the same location. Recordings were then made through the solution in the pipette to verify the LGN laminar position of the pipette for centering the injections within the K3 layer. Next, WGA-HRP (approximately $2 \mu \mathrm{L}$ ) was pressure injected slowly over 8 minutes. Each injection was large enough to cover all the LGN layers within zones approximately one-third to one-half of the volume of the LGN. When the injection was complete, the pipette was removed, the dural flap was repositioned, and the skin was sutured.

Postoperatively, all animals were given $0.01 \mathrm{mg} / \mathrm{kg}$ of buprenorphine (Buprenex, Reckitt Benckiser Pharmaceuticals, Inc, Richmond, VA, USA) as analgesic and 300,000 units/kg of long-acting penicillin (Flo-Cillin; Fort Dodge Animal Health, Fort Dodge, IA, USA) and monitored carefully until they were fully conscious and capable of eating and drinking on their own. At that point, animals were returned to their home cages and provided with soft, palatable foods and water.

\section{Histological procedures}

After a 2-day survival period, the animals were deeply anesthetized with an overdose of sodium pentobarbital (Nembutal Sodium; Lundeck Inc., Deerfield, IL, USA). 
The animals were initially perfused transcardially with a brief rinse of oxygenated saline, then perfused with $2.0 \%$ paraformaldehyde (Electron Microscopy Sciences, Hatfield, PA, USA) and 1.5\% glutaraldehyde (Electron Microscopy Sciences) in a $0.1 \mathrm{M}$ phosphate buffer $(\mathrm{pH} 7.4)$ at $4{ }^{\circ} \mathrm{C}$, and finally with the same fixative containing $4.0 \%$ sucrose. The brains were removed and postfixed in $4.0 \%$ sucrose in the same fixative at $4^{\circ} \mathrm{C}$ for 1 hour. The tissue then was rinsed three times in $0.1 \mathrm{M}$ phosphate buffer $(\mathrm{pH} 7.4)$ and placed in $4.0 \%$ sucrose in the same buffer at $4^{\circ} \mathrm{C}$ overnight.

The following day, the visual cortex was blocked anterior to the secondary visual cortex (V2) and was dissected from the remainder of the cortical hemisphere. Then, parasagittal or coronal sections were cut on a vibratome (Vibroslice; Campden Instruments Ltd., Loughborough, UK). Sections were cut at different thicknesses with a typical series being four $60 \mu \mathrm{m}$ sections, two immunostained for mGluR5 (see the Light microscopy section) with the adjacent two stained for Nissl bodies and $\mathrm{CO}$, and two were cut at $15 \mu \mathrm{m}$ and immunostained for mGluR5. The thalamus was frozen sectioned either parasagittally or coronally at $52 \mu \mathrm{m}$ on a freezing microtome (American Optical Company, Buffalo, NY, USA). Two uninjected macaques also were perfused as described but with $3 \%$ paraformaldehyde, $0.1 \%$ glutaraldehyde, and $0.2 \%$ saturated picric acid (volumevolume), followed by the same fixative with $10 \%$ sucrose. All sections from these two animals were cut frozen at $52 \mu \mathrm{m}$.

\section{WGA-HRP histochemistry}

All cortical and LGN sections from animals injected with WGA-HRP were treated with a modified-tetramethylbenzidine stabilization procedure. ${ }^{44,45}$ Sections to be used for LM were mounted on gelatin-coated slides, air-dried, defatted, dipped briefly in a clearing agent (Histo-Clear ${ }^{\circledR}$ [National Diagnostics, Atlanta, GA, USA] or Citrisolv ${ }^{\mathrm{TM}}$ [Fisher Scientific, Pittsburgh, PA, USA]), and coverslipped. Counterstaining was unnecessary in these cases, since LGN and cortical layers were clearly visible in the tetramethylbenzidine-treated sections. All LGN injection sites were reconstructed from serial sections using a microprojector (Bausch \& Lomb Incorporated, Bridgewater, NJ, USA) at low magnification $(170 \times)$ to document the location and extent of the WGA-HRP label in relation to the layers of the LGN. All injection reconstructions showed that the injection pipette was centered on layer $\mathrm{K} 3$ and that the label spread throughout the $\mathrm{P}$ and $\mathrm{M}$ layers above and below this location.

\section{Light microscopy}

Sections prepared for immunocytochemistry to reveal the presence of mGluR5 were treated as follows. Initially, sections were treated with sodium borohydride $(1 \%$ in phosphate buffered saline [PBS]) for 20 minutes, rinsed in PBS, and preincubated for 1 hour with $10 \%$ normal goat serum (NGS) in a PBS-BSA solution (0.05\% Tween 20, $0.005 \%$ bovine serum albumin [BSA], and $0.001 \%$ gelatin; all from Sigma-Aldrich in PBS) before being incubated for 48 hours at $4{ }^{\circ} \mathrm{C}$ with primary antibody (mGluR5, $5 \mu \mathrm{g} / \mathrm{mL}$ ) raised against a 21 residue synthetic peptide (KSSPKYDTLIIRDYTNSSSSL), corresponding to the C-terminus of mGluR5 with a lysine added to the N-terminus (Upstate Biotechnology, Lake Placid, NY, USA) in 1\% NGS in PBS-BSA. The sections were then incubated for 2 hours with a secondary antibody, biotin-conjugated donkey antirabbit IgG (Bioscience Research Reagents [formerly Chemicon], Temecula, CA, USA) diluted 1:1,000 in 1\% NGS/PBS-BSA solution. The sections were rinsed three times for 10 minutes each in PBS and incubated in avidinbiotin complex (ABC; Vector Labs, Burlingame, CA, USA) at a dilution of 1:100 in PBS for 30 minutes. After rinsing the sections in PBS three times for 10 minutes each, diaminobenzidine tetrahydrochloride (DAB; Sigma-Aldrich) was used in conjunction with hydrogen peroxide to visualize the reaction. Cobalt chloride (Sigma-Aldrich) was used to intensify this reaction. Some of these sections were taken for further EM study and were embedded in EPONTM Resin (Electron Microscopy Sciences), as described in the following section. The remaining sections were mounted on gelatin-coated slides, air dried, defatted, cleared with a clearing agent (Histo-Clear ${ }^{\circledR}$ or Citrisolv ${ }^{\mathrm{TM}}$ ) and coverslipped.

For the two uninjected macaques, sections were rinsed in Tris-buffered saline (TBS) and blocked by incubating them in $3 \%$ normal donkey serum, $0.1 \%$ sodium azide, $0.2 \%$ Triton $^{\mathrm{TM}}-\mathrm{X}$ 100 , and $2 \%$ cold water fish gelatin (all from Sigma-Aldrich) in TBS for 1 hour, followed by blocking for 15 minutes in 1\% sodium nitroferricyanide (Sigma-Aldrich) and 1\% acetic acid in absolute methanol. The sections were then rinsed with $0.1 \%$ sodium azide, $0.2 \%$ Triton $^{\mathrm{TM}}-\mathrm{X} 100$, and $0.5 \%$ cold water fish gelatin in TBS (antibody buffer) and left for 24 hours at $4^{\circ} \mathrm{C}$. The primary and secondary antibodies were applied in concentrations of $1: 1,000$ and 1:500, respectively. The sections were incubated for 48 hours with the primary antibody (EMD Millipore, Billerica, MA, USA), rinsed with antibody buffer, incubated for 24 hours with the secondary antibody (donkey antirabbit; EMD Millipore), and then rinsed again with antibody buffer followed by TBS. Vector ABC Standard Elite kit was used to bind horseradish peroxidase (HRP) to the biotin in the secondary antibody ( 2 hours) and then DAB was used in combination with hydrogen peroxide to visualize the proteins. 
In all cases, some sections were run without primary antibody as negative controls. All sections were mounted on gelatin-coated slides, air-dried, defatted, cleared with a clearing agent $\left(\mathrm{Citrisolv}^{\mathrm{TM}}\right)$, and coverslipped. LM photographs were taken with a SPOT camera (SPOT Imaging Solutions, Sterling Heights, MI, USA). Some high-power images were taken at multiple focal planes and deconvolved using CombineZP Image Stacking Software (Alan Hadley, Sheffield, UK).

For CO staining, we used the method described by Wong-Riley, ${ }^{46}$ as modified by Boyd and Matsubara. ${ }^{47}$ For cell staining, we used $0.5 \%$ Cresyl Violet (Chroma-Gesellschaft, Kongen, Germany).

\section{Electron microscopic preembedding immunocytochemistry}

Sections prepared for EM also were treated with sodium borohydride (1\% in PBS) for 20 minutes, rinsed in PBS, and a preembedding immunocytochemical technique was applied as described by Hanson and Smith. ${ }^{48}$ Briefly, the sections were preincubated for 1 hour with 10\% NGS in a PBS-BSA solution $(0.05 \%$ Tween 20 [Sigma-Aldrich], $0.005 \%$ BSA [Sigma-Aldrich], and $0.001 \%$ gelatin [ 75 bloom, SigmaAldrich] in PBS) before being incubated for 48 hours at $4^{\circ} \mathrm{C}$ with primary antibody (mGluR5, $5 \mu \mathrm{g} / \mathrm{mL}$; Upstate Biotechnology) in 1\% NGS/PBS-BSA solution.

The sections were then incubated for 2 hours with secondary antibody, goat antirabbit IgG conjugated to $1 \mathrm{~nm}$ gold particles (Ted Pella Inc., Redding, CA, USA) diluted 1:100 in 1\% NGS/ PBS-BSA solution. After fixation in 1\% glutaraldehyde for 1 hour, the sections were rinsed with PBS, and gold particles were silver-intensified for 6 minutes with a Silver Enhancer Kit (Sigma-Aldrich) and rinsed again with PBS. As controls, in some sections primary antibody was omitted, while the rest of the procedure was kept the same. Sections processed in this way were totally devoid of silver grains. All cortical sections were postfixed with $1.0 \%$ osmium tetroxide (Sigma-Aldrich), in $0.1 \mathrm{M}$ phosphate buffer at $4^{\circ} \mathrm{C}$ and stained en bloc with uranyl acetate (Electron Microscopy Sciences) 2.0\% solution in $70 \%$ ethanol, for 1 hour at $4^{\circ} \mathrm{C}$, subsequently dehydrated in an ascending series of graded ethanols and embedded in EPON $^{\text {TM }}$ Resin overnight.

After polymerization at $60^{\circ} \mathrm{C}$ for 2 days and prior to ultrathin sectioning, slices containing the WGA-HRP labeled LGN axons were examined carefully at the LM level and regions containing the most intense patches of label in cortical layer III and continuous label throughout the full thickness of layer IVC were dissected from the remainder of the tissue with a NeuroPunch (Ted Pella Inc.). Within the cortical areas, the selected clear axonal label was evident within layer VI, both halves of layer IVC (IV), IVA (IIIB $\beta$ ), the CO blob zones in layer III (IIIB $\alpha$ ), and layer I demonstrating that all P, M, and K LGN layers were involved in the injection. The neuropunches were centered either on the patches of K WGA-HRP labeled axons within layer III (IIIB $\alpha$ ) or included all of layer IVC (IV) ( $\mathrm{M}$ and $\mathrm{P}$ axons). Since $\mathrm{K}$ axons terminate as patches in layer III (IIIB $\alpha$ ) that colocalize with the CO blobs in all species that have been examined, including macaque monkeys and squirrel monkeys, ${ }^{2,9,41,43,49,50}$ and layer IVC (IV) is a well-investigated recipient layer of input signals from the $\mathrm{M}$ and $\mathrm{P}$ axons in these species, we made the assumption that the patches of label visualized within layer III (IIIB $\alpha$ ) and the continuous label visualized in layer IVC (IV) originated from $\mathrm{K}$ and $\mathrm{M} / \mathrm{P}$ axons, respectively. No effort was made to divide layer IVC (IV) into separate $\mathrm{M}$ and $\mathrm{P}$ recipient zones in advance of analysis.

Ultrathin sections (approximately $70 \mathrm{~nm}$ ) were cut with a diamond knife using an Ultracut E (Reichert-Jung, Wein, Austria) and collected on uncoated 200-mesh nickel grids (Electron Microscopy Sciences). After washing in deionized water, the sections were counterstained with uranyl acetate and lead citrate $^{50}$ (Electron Microscopy Sciences) and examined using a Hitachi H-800 transmission electron microscope (Hitachi Ltd, Tokyo, Japan) with an acceleration voltage of $100 \mathrm{kV}$.

\section{Data collection and analysis}

At the LM level, the degree of mGluR5 labeling in the neuropil and cells was examined in each cortical layer. Layer assignments were made by matching blood vessel patterns of immunostained sections with adjacent sections stained for CO or Nissl bodies. Boundaries of layer IVC (IV) were based upon $\mathrm{CO}$ sections, since the dark label tends to mark the location of LGN input from the $\mathrm{P}$ and M pathways.

At the EM level, all labeled LGN axon terminals (WGAHRP positive) making synaptic contact were analyzed from both squirrel monkey and macaque monkey in at least three different punches (ie, separate blocks) in ten sections from each punch. Terminal labeling and synapse identification were confirmed by examining at least two adjacent sections. To determine the proportion of the thalamic afferents that contain mGluR5 or synapse with mGluR5 targets, all labeled (WGAHRP positive) terminals were photographed at 20,000×, and the target and its microenvironment were assessed.

Since control sections contained no label, pre- and postsynaptic targets (dendritic shafts and spines) were considered mGluR5 positive if they contained one or more grains of silver. The total area examined in the CO-blobs (K axons) and layer IVC (IV) (M and P axons) was nearly 
the same (in squirrel monkeys $1,094.4 \mu \mathrm{m}^{2}$ for CO-blobs and $1,039.68 \mu \mathrm{m}^{2}$ for layer IVC [IV], and in macaque monkeys $437.76 \mu \mathrm{m}^{2}$ for CO-blobs and $492.48 \mu \mathrm{m}^{2}$ for layer IVC [IV]). Because $\mathrm{M}$ axon terminals have been reported ${ }^{8,51,52}$ to be significantly larger than the $\mathrm{P}$ axon terminals, we examined the areas in $\mu \mathrm{m}^{2}$ of axon terminals presynaptic to mGluR5labeled dendrites in layer IVC to see if there was a tendency for more of the larger (presumed $\mathrm{M}$ axons) or more of the smaller (presumed $\mathrm{P}$ axons) to terminate preferentially on mGluR5-labeled dendrites. Areal calculations were done on photomicrographs at $20,000 \times$ magnification.

In the present study, we used the criteria proposed originally by Freund et al $^{51}$ to distinguish dendritic spines from shafts. According to their criteria, all dendritic profiles that contain mitochondria and/or microtubules were classified as dendritic shafts, regardless of their diameter. All profiles lacking mitochondria and microtubules were classified as dendritic spines.

For LM analysis, we examined all layers as well as the white matter at low $(4 \times)$ and high power $(60 \times$ oil) from all cases to examine qualitatively for differences in the label density and the distribution of the mGluR5 label within cells and potential axons within each layer. Special attention was paid to the sublaminae known to receive the bulk of the direct input from $\mathrm{K}, \mathrm{M}$, and $\mathrm{P}$ LGN axons that were not sampled separately at the EM level. These layers included layer I and layer IVA (IIIB $\beta$ ), which receive input from $\mathrm{K}$ axons in both the macaque monkey and the squirrel monkey, and layer VI which receives input from the collaterals of most $M$ axons as well as some $\mathrm{P}$ axons.

\section{Results}

Our LM and EM results show that - in both squirrel and macaque monkeys - the expression of mGluR5 in each of the main parallel LGN channels is quite distinct. In the K pathway, all axons examined contained mGluR 5 protein and $30 \%$ of the postsynaptic dendrites also contained this receptor. In layer IVC (IV), none of the LGN axons contained mGluR5 at either the LM or the EM level. This receptor appeared to be present only in dendrites that receive synapses from the smaller (presumably P) axon terminals. Details concerning these results and their interpretation are provided in the following section.

\section{Laminar distribution of mGluR5}

The laminar distribution of mGluR5-visualized by HRPDAB in V1 of a squirrel monkey at the LM level is shown in Figure 2A. The laminar boundaries are indicated in an

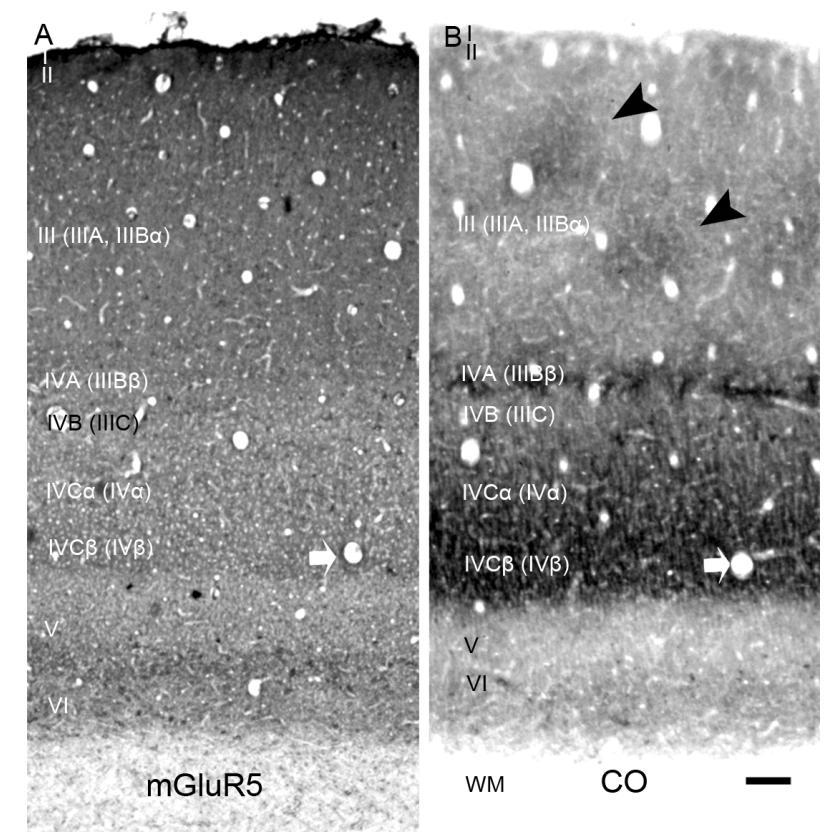

Figure 2 Laminar location of mGluR5 (A) in comparison to a CO-stained adjacent section (B) in the squirrel monkey. mGluR5 is dense in all layers except the upper tier of IVC $\alpha(I V \alpha)$ and layer V. Common blood vessels are marked with white arrows on the two sections. CO blobs are designated with black arrowheads. Roman numerals refer to the cortical layers using the laminar designation of Brodmann ${ }^{5}$ with the nomenclature of Hässler ${ }^{6}$ in parentheses; see also Casagrande and Kaas. ${ }^{3}$ Note: Scale bar $=50 \mu \mathrm{m}$.

Abbreviations: mGluR5, metabotropic glutamate receptor 5; $\mathrm{CO}$, cytochrome oxidase; WM, white matter.

adjacent section (Figure 2B) stained for CO. Note that in squirrel monkeys, mGluR5 immunostaining is especially dense in all layers above layer IVC (IV) and very weak within layers IVC $\alpha(I V \alpha)$ and V. With a few minor differences, a similar laminar distribution of immunostaining for mGluR5 was seen in V1 of the macaque monkeys. As shown in Figure 3A, in the macaque, as in the squirrel monkey, the most dense label was in the superficial layers above layer IVB (IIIC), especially in layer IVA (IIIB $\beta$ ) and layer I. At high power, layer I (Figure 3B) showed clear evidence of mGluR5-labeled axons. Distinct axon labeling was not seen at the LM level in any other LGN K axon target layers, such as the CO blob-aligned region of layer III (Figure 3C), which looked similar at high power to the mGluR5-labeled interblob-aligned regions (Figure 3D). Although very dark neuropil was evident in IVA (IIIB $\beta$ ), no axons were seen in this layer, either (Figure 3E).

In the macaque as in the squirrel monkey, IVC $\alpha$ (IV $\alpha$ ) had very little above background label but clear mGluR5positive neuropil was evident in IVC $\beta$ (IV $\beta$ ), especially as a thin band at the base of the layer (Figure 3F). Unlike the squirrel monkey, which showed above background label in 

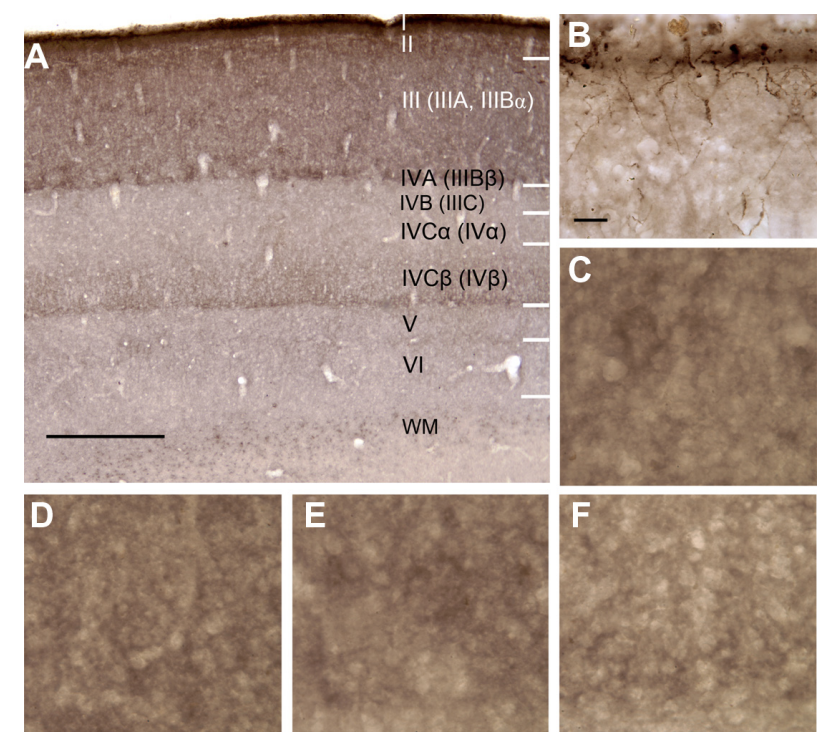

Figure 3 Laminar location of mGluR5 in macaque monkey. As seen at low power (A), the heaviest staining is in layer I and layer II, with heavy staining in layer III as well. IVA (IIIB $\beta$ ) and IVC $\beta$ (IV $\beta$ ) also show dark bands. (B) Axons immunopositive for mGluR5 in layer I and layer II. (C) Layer III, within a CO blob. (D) Layer III within an interblob. (E) Dense staining in layer IVA (IIIB $\beta)$. (F) Dense staining in layer IVC $\beta$ (IV $\beta)$.

Notes: Scale bar in $(\mathbf{A})=500 \mu \mathrm{m}$; in (B-F), scale bar $=20 \mu \mathrm{m}$.

Abbreviations: mGluR5, metabotropic glutamate receptor 5; CO, cytochrome oxidase;WM, white matter.

layer VI, this layer was very light in the macaque monkey, and more above background label was seen in a portion of layer V. It is also noteworthy that, although the patterns were similar, the overall density of the mGluR5 label varied between cases.

In general, the label appeared punctate within the neuropil. Bands of label could also be seen passing vertically through some sections, which may represent bundles of pyramidal cell apical dendrites. ${ }^{53,54}$ Higher power examination revealed that a few cells, mainly pyramidal in both the squirrel monkey and the macaque monkey were stained within all layers, but these were most evident within layer VI of the squirrel monkey, where staining was generally confined to the soma. In other layers, such as layer III (IIIB $\alpha$ ), mGluR5 was also seen in the processes, such as the apical dendrites of the stained cells, as can be seen in Figure 4. Within the white matter, mGluR5 was evident in what appeared to be axons (arrows, Figure 5), as well as within astrocytes indicated by arrowheads within the same figure.

\section{mGluR5 in dendrites and cell bodies}

At the EM level, immunogold-labeled profiles were easily identified, based upon the presence of silver-enhanced gold particles. Few immunogold particles were observed in the cell

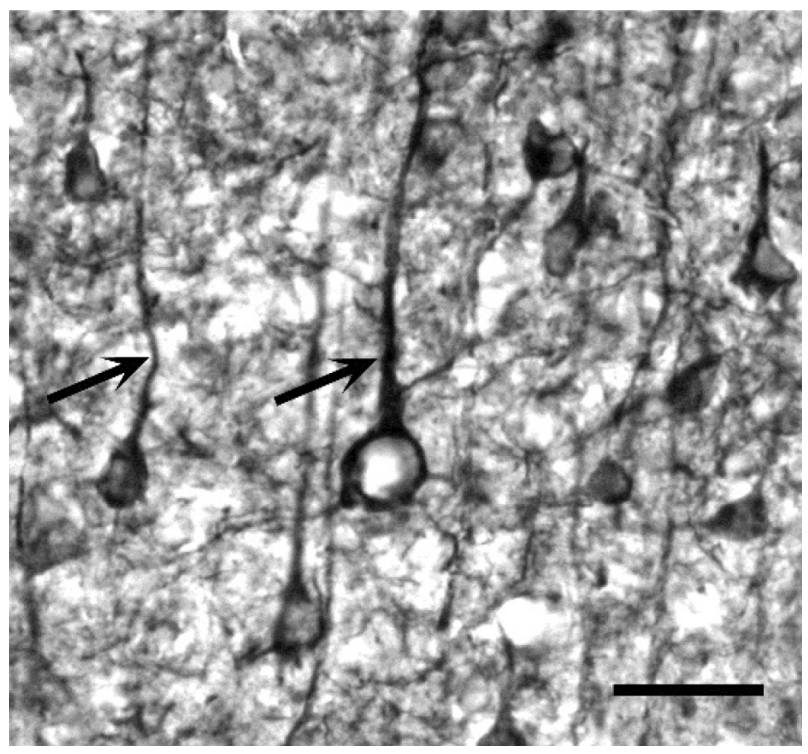

Figure 4 mGluR5 immunostaining of cells within layer II in a macaque monkey. Very few cells were stained with the antibody to mGluR5; most appeared to be pyramidal cells (arrows).

Note: Scale bar $=20 \mu \mathrm{m}$.

Abbreviation: mGluR5, metabotropic glutamate receptor 5 .

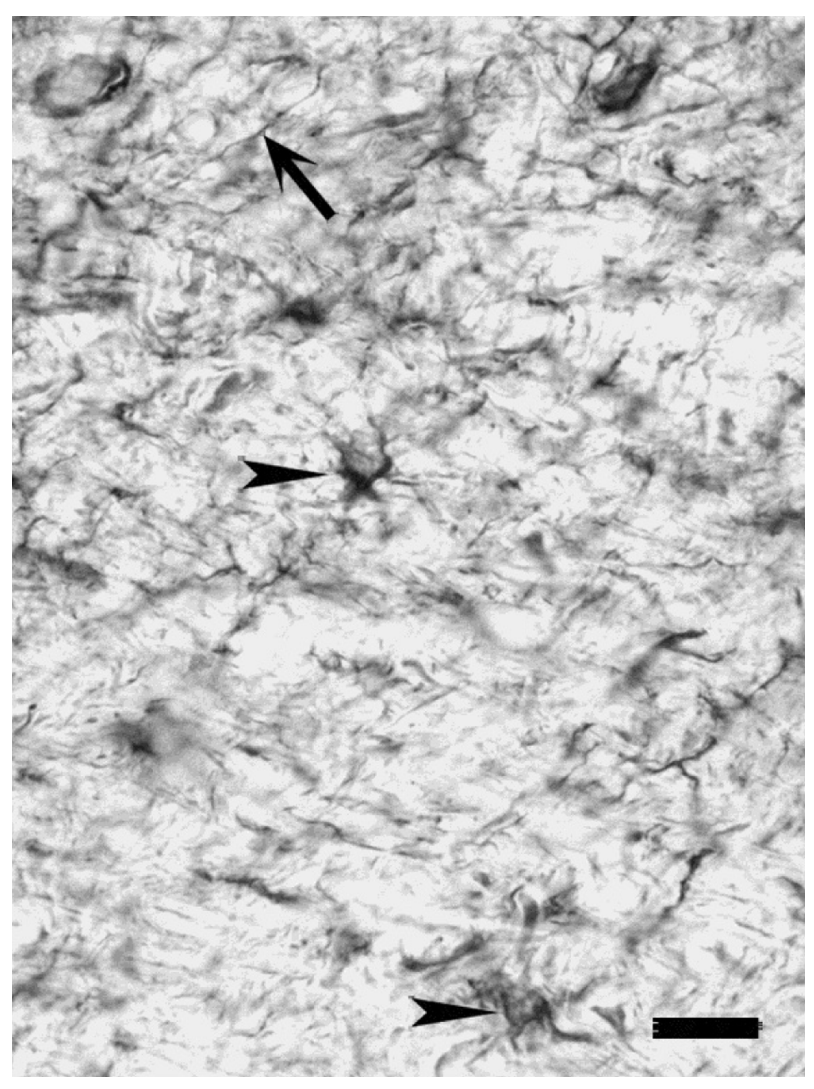

Figure 5 mGluR5 immunostained axon (arrow) and astrocytes (arrowheads) were seen occasionally in white matter. The astrocyte on the right bottom is slightly out of focus.

Note: Scale bar $=20 \mu \mathrm{m}$.

Abbreviation: mGluR5, metabotropic glutamate receptor 5 . 
bodies in either layer IVC (IV) or layer III (IIIB $\alpha$ ) in either primate. Despite the virtual absence of cell body labeling, large numbers of dendritic-labeled processes were detected in the neuropil. mGluR5 labeling was seen within dendritic shafts and spines, along the plasma membrane, as well as within the cytoplasm of processes in both layer IVC (IV) and the $\mathrm{CO}$ blob locations of layer III (IIIB $\alpha$ ) in both species (Figures 6 and 7). Within the areas measured in both cortical layers, about one-third to one-half of the dendritic profiles (both shafts and spines) contained gold particles indicative of the presence of mGluR5 (Table 1).

The only species difference evident at the EM level was that the proportion of immunopositive shafts to immunopositive spines was closer to $2: 1$ in macaque monkey layer III (IIIB $\alpha)$; whereas, in squirrel monkey layer III (IIIB $\alpha)$, it was closer to 1:1 (Table 1). It was noteworthy, however, that we only sampled in the portion of layer III that aligned with the patches of LGN K-labeled axons (the CO blobs). Also, since we only had two squirrel monkeys in this study, the $\mathrm{N}$ is small enough that we cannot be certain this result reflected a real species difference rather than an individual difference.

We also asked if there were differences that might relate to the M and P pathways within layer IVC (IV). Since we did not

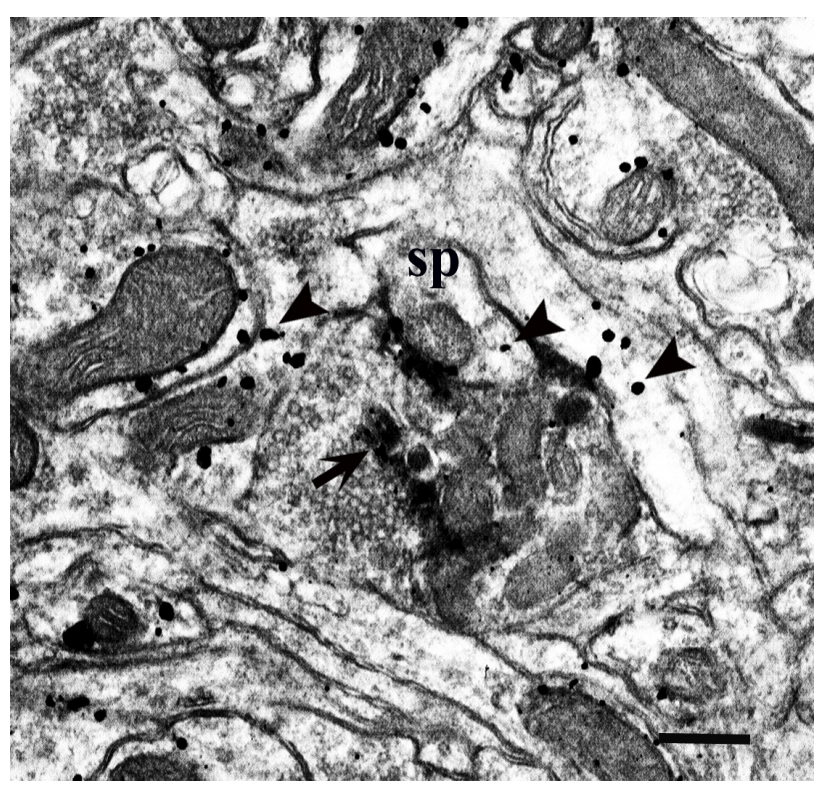

Figure 6 A WGA-HRP labeled LGN M/P axon within layer IVC (IV) of a squirrel monkey. The WGA-HRP electron-dense reaction product is indicated by an arrow. The spine postsynaptic to this axon terminal contains silver grains (seen as larger black dots) indicative of the presence of mGluR5 (arrowheads), but the axon itself does not. Other dendrites nearby also show evidence of mGluR5 labeling.

Note: Scale bar $=0.5 \mu \mathrm{m}$.

Abbreviations: sp, spine; WGA-HRP, wheat germ agglutinin-horseradish peroxidase; LGN, lateral geniculate nucleus; M/P, magnocellular/parvocellular; mGluR5, metabotropic glutamate receptor 5 .

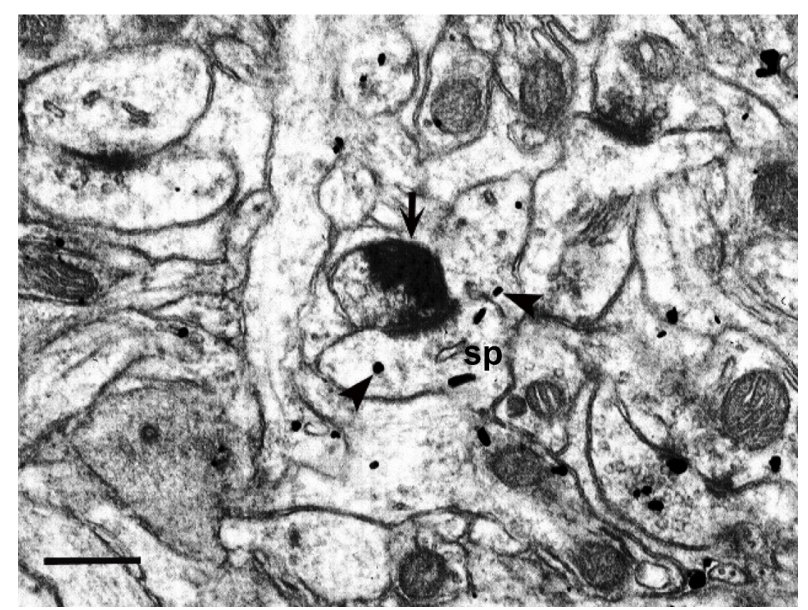

Figure 7 A WGA-HRP labeled LGN M/P axon within IVC (IV) in a macaque monkey. Arrow indicates WGA-HRP electron dense reaction product in the axon. The spine postsynaptic to this axon contains silver grains indicative of the presence of mGluR5 (arrowheads) but the axon does not. Other dendrites are also labeled. Note: Scale bar $=0.5 \mu \mathrm{m}$.

Abbreviations: WGA-HRP, wheat germ agglutinin-horseradish peroxidase; LGN, lateral geniculate nucleus; M/P, magnocellular/parvocellular; mGluR5, metabotropic glutamate receptor 5; sp, spine.

restrict our original samples to either IVC $\alpha$ (IV $\alpha$ ) (M input) or IVC $\beta$ (IV $\beta$ ) (P input), we instead measured the sizes of all WGA-HRP positive labeled axons that synapsed with mGluR5 positive versus mGluR5 negative dendrites (shafts and spines) to see if there were differences in the mean sizes of these axon terminals. Since M axon terminals are known to be larger than $\mathrm{P}$ axon terminals, ${ }^{7,51,52}$ we reasoned that if the pathways differed in their synaptic termination patterns with respect to mGluR5-positive dendrites, this difference should be reflected in a shift in the mean size of the axon terminals synapsing with these dendrites.

Interestingly, the data show that there was a difference in the sizes of axon terminals synapsing with mGluR5-positive dendrites. The data show that in the macaque monkey the average size (mean \pm standard error, $\mu \mathrm{m}^{2}$ ) of the axon terminals synapsing with mGluR5-positive dendrites was smaller $\left(0.94 \pm 0.12 \mu \mathrm{m}^{2}\right)$ than the average size of the axons synapsing with mGluR5-negative dendrites $\left(1.37 \pm 0.00 \mu \mathrm{m}^{2}\right)$. Similarly, in the squirrel monkey, the axon terminals synapsing with mGluR5-positive dendrites were smaller (1.05 \pm 0.16 $\mu \mathrm{m}^{2}$ ) than those synapsing with immunonegative dendrites $\left(1.31 \pm 0.15 \mu \mathrm{m}^{2}\right)$.

Since there is a size overlap between the $\mathrm{P}$ and $\mathrm{M}$ populations, we cannot be certain that this reflects a true difference between the $\mathrm{P}$ and $\mathrm{M}$ axons. It does fit nicely with the LM picture however, which clearly shows that mGluR5 is significantly lower in density in IVC $\alpha(\operatorname{IV} \alpha)$ than in IVC $\beta$ (IV $\beta$ ) (Figures 2A and 3A). 
Table I Percentage of dendrites containing mGluR5

\begin{tabular}{|c|c|c|c|c|c|}
\hline \multirow[t]{2}{*}{ Species } & \multirow{2}{*}{$\begin{array}{l}\text { Cortical } \\
\text { layer }\end{array}$} & \multicolumn{2}{|c|}{ Dendritic shafts } & \multicolumn{2}{|c|}{ Dendritic spines } \\
\hline & & Positive & Negative & Positive & Negative \\
\hline \multirow[t]{2}{*}{ MM } & III (IIIB $\alpha)$ & $57 \%(n=78)$ & $43 \%(n=59)$ & $26 \%(n=28)$ & $74 \%(n=79)$ \\
\hline & IVC (IV) & $37 \%(n=42)$ & $63 \%(n=71)$ & $28 \%(n=33)$ & $72 \%(n=83)$ \\
\hline \multirow[t]{2}{*}{ SM } & III (IIIB $\alpha)$ & $35 \%(n=77)$ & $65 \%(n=140)$ & $36 \%(n=52)$ & $64 \%(n=92)$ \\
\hline & IVC (IV) & $31 \%(n=42)$ & $69 \%(n=95)$ & $34 \%(n=37)$ & $66 \%(n=7 I)$ \\
\hline
\end{tabular}

Notes: Roman numerals indicate VI layers. Cortical layers as designated by Brodmann ${ }^{5}$ with a modified version of Hässler's ${ }^{6}$ nomenclature in parenthesis. Note that the samples in layer III were restricted to punches taken to match the location of CO blobs on adjacent sections.

Abbreviations: mGluR5, metabotropic glutamate receptor 5; VI, primary visual cortex; MM, macaque monkey; SM, squirrel monkey; CO, cytochrome oxidase.

\section{Presynaptic localization of mGluR5}

Our results also revealed presynaptic mGluR5 labeling indicative of autoreceptors within the WGA-HRP labeled $\mathrm{K}$ axons sampled in layer III (IIIB $\alpha$ ). Amazingly, $100 \%$ of these K-labeled axons $(\mathrm{N}=33)$ were immunopositive. The same result was found in both primate species. Figures 8 and 9 show examples of immunopositive $\mathrm{K}$ axons synapsing with dendritic spines in a squirrel monkey and a macaque monkey, respectively. In Figure 8, postsynaptic spines are immunonegative for mGluR5, although about $30 \%$ of the time both pre- and postsynaptic elements were immunopositive (Figures 10 and 11). Postsynaptic labeling was mostly found in spines, but it also could be seen in dendritic shafts

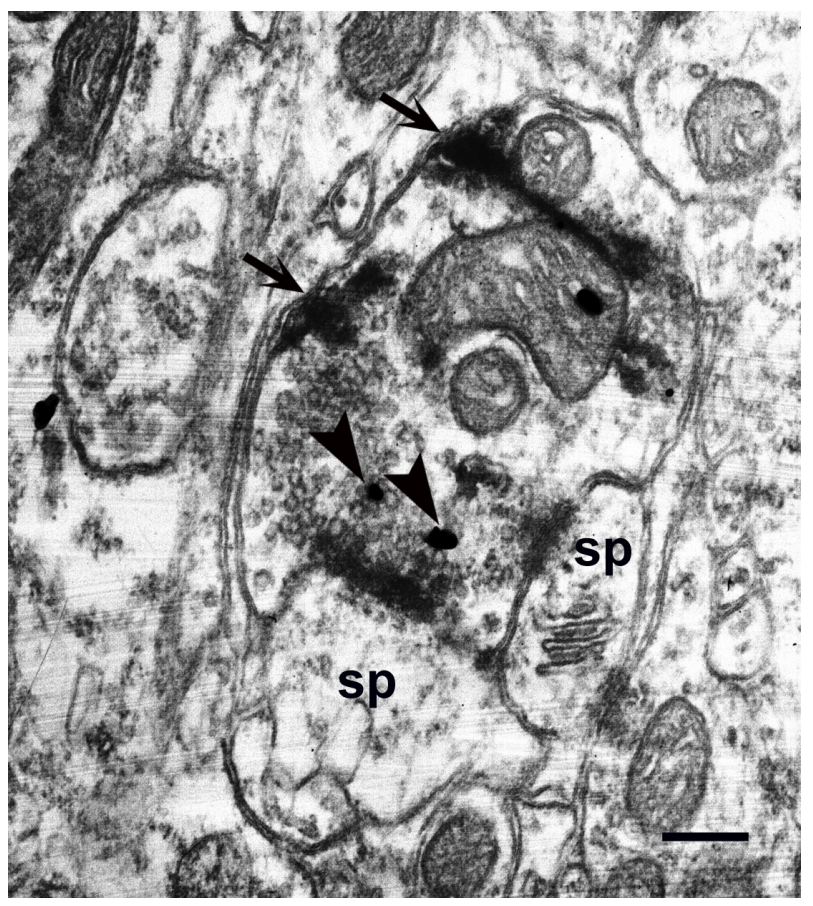

Figure 8 mGluR5 immunoreactivity (arrowheads) is present in a WGA-HRP labeled $\mathrm{K}$ axon terminal, identified by electron-dense reaction product (arrows) in layer III of a squirrel monkey. This $\mathrm{K}$ axon contacts two spines that are immunonegative for mGluR5.

Note: Scale bar $=0.5 \mu \mathrm{m}$

Abbreviations: mGlurR5, metabotropic glutamate receptor 5; WGA-HRP, wheat germ agglutinin-horseradish peroxidase; sp, spine; K, koniocellular. opposite K axons (Figure 10). As with postsynaptic labeling, the presynaptic gold particles indicative of the presence of mGluR5 could occur along the plasma membrane adjacent to the synapse or within the cytoplasm associated with the synaptic vesicles (Figures 10 and 11). Gold particles were rarely found directly over the synapse itself.

\section{Discussion}

These results are the first to show that metabotropic glutamate receptors are distributed in distinct ways within the different LGN parallel pathways. Presynaptic mGluR5 was found only within the $\mathrm{K}$ pathway; all $\mathrm{K}$ axons examined that were located in layer III (IIIB $\alpha$ ) in both primate species were immunopositive for this receptor. Although not examined at the EM level, mGluR5 labeled presumed LGN K axons were seen in layer I and layer II but not in IVA (IIIB $\beta$ ) and

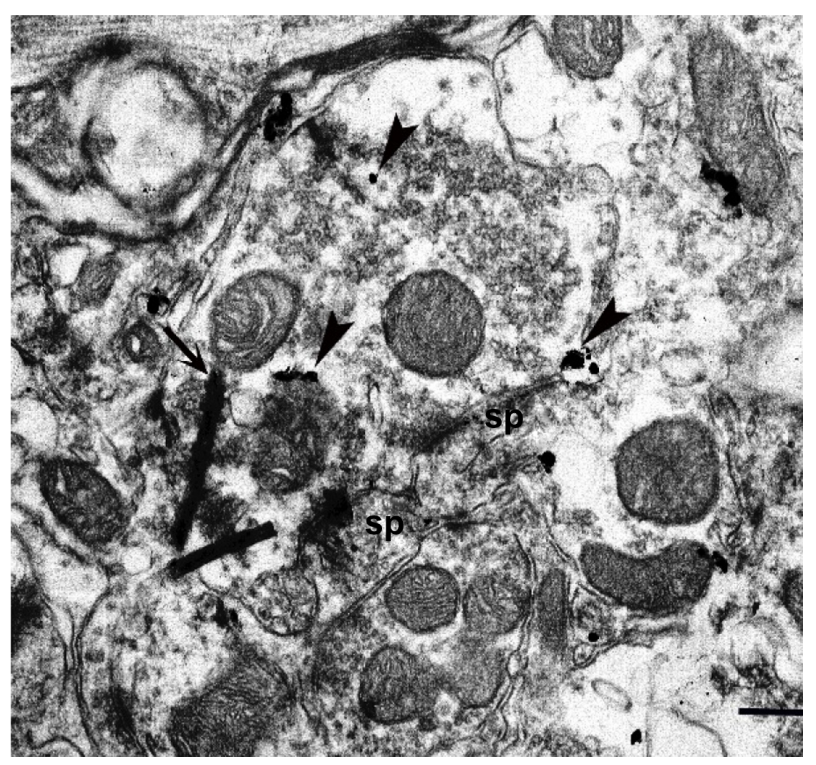

Figure 9 mGluR5 immunoreactivity (arrowheads) is present in a WGA-HRP labeled $\mathrm{K}$ axon terminal, identified by electron-dense reaction product (arrow) in layer III of a macaque monkey. This $\mathrm{K}$ axon contacts two spines that are immunonegative for mGluR5.

Note: Scale bar $=0.5 \mu \mathrm{m}$.

Abbreviations: mGluR5, metabotropic glutamate receptor 5; WGA-HRP, wheat germ agglutinin-horseradish peroxidase; K, koniocellular; sp, spine. 


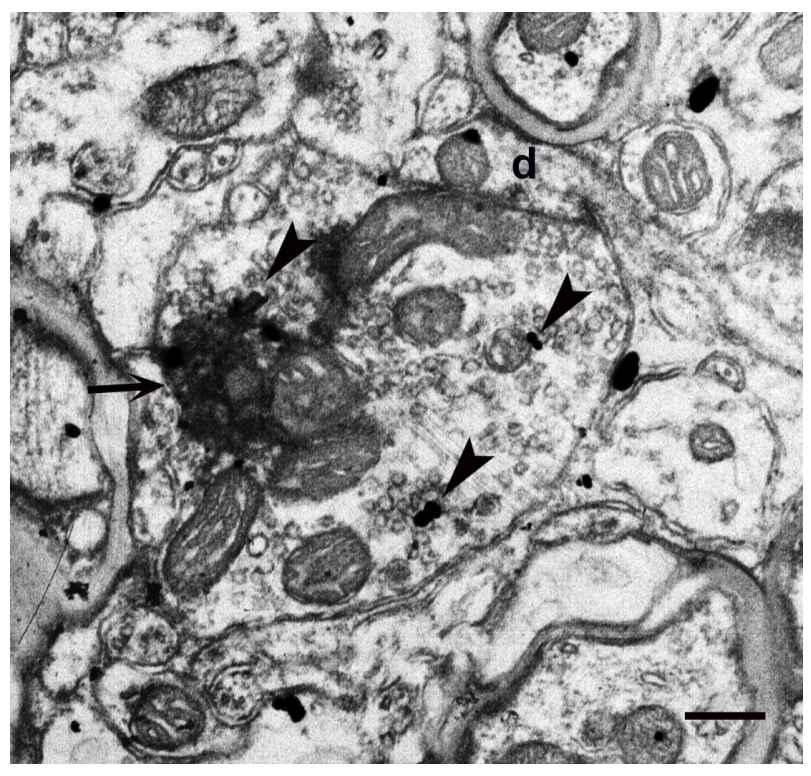

Figure 10 mGluR5 immunoreactivity visualized with silver grains as the label (arrowheads) is present in the $\mathrm{K}$ axon terminal in layer III (squirrel monkey) as well as in the postsynaptic dendritic shaft (marked as d). Arrow indicates electron-dense WGA-HRP reaction product in the $\mathrm{K}$ axon.

Note: Scale bar $=0.5 \mu \mathrm{m}$.

Abbreviations: mGluR5, metabotropic glutamate receptor 5; WGA-HRP, wheat germ agglutinin-horseradish peroxidase; $\mathrm{K}$, koniocellular.

were present within the white matter. mGluR5 was not found to colocalize with $\mathrm{M}$ or $\mathrm{P}$ labeled axons, but was found in $30 \%-50 \%$ of dendrites postsynaptic to $\mathrm{M}$ and $\mathrm{P}$ axons. Within layer IVC (IV), however, mGluR5 was found preferentially within dendrites postsynaptic to smaller (presumed

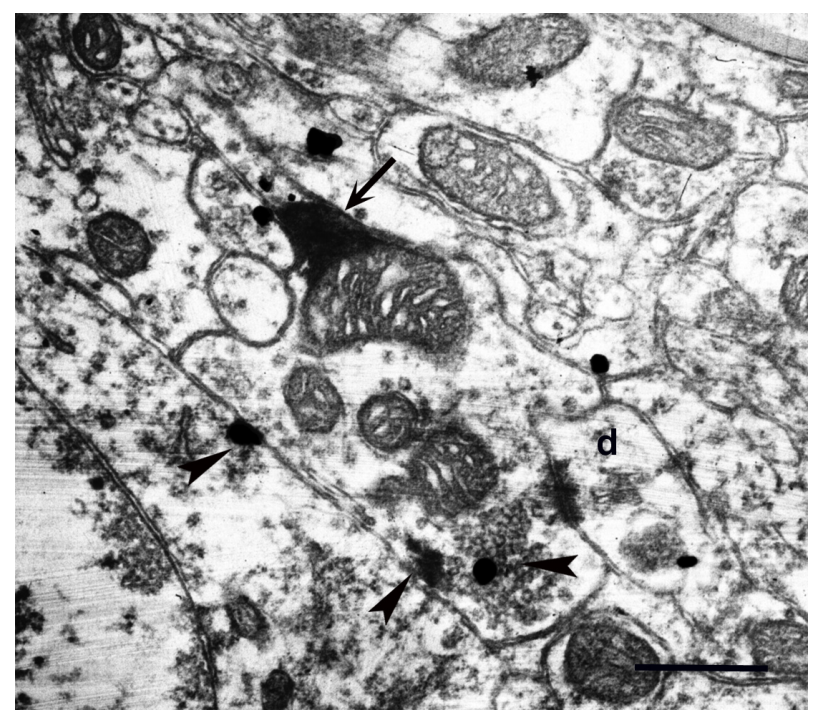

Figure II mGluR5 immunoreactivity (arrowheads) is present in a WGA-HRP (arrow indicates electron-dense reaction product) labeled $\mathrm{K}$ axon terminal in layer III of macaque monkey $\mathrm{VI}$ which makes contact with an immunopositive dendritic shaft (marked as d).

Note: Scale bar $=0.5 \mu \mathrm{m}$.

Abbreviations: mGluR5, metabotropic glutamate receptor 5; WGA-HRP, wheat germ agglutinin-horseradish peroxidase; K, koniocellular.
P LGN-labeled axons) not larger (presumed M LGN-labeled axons), suggesting that this receptor may selectively regulate the P, not the M pathway within layer IVC (IV). In the "Relationship to previous studies" section, we consider the relationship of these findings to previous studies and their functional implications.

\section{Relationship to previous studies}

Our LM results showed that mGluR5 in macaque and squirrel monkey V1 is dense in the superficial neuropil and in a few (mainly pyramidal) cells in all layers. It was above background in all layers but barely so within IVC $\alpha(\operatorname{IV} \alpha)$ and IVB (IIIC). In addition, we found that mGluR5 is present within fibers and presumed astrocytes in the white matter. It is noteworthy that a different pattern of mGluR5 staining was reported for area 17 (primary visual cortex) in the cat. ${ }^{21}$ In the cat and the monkey, the densest concentration of LGN input is in layer IV. In the cat, this layer also was reported to have the highest concentration of mGluR5, ${ }^{21}$ suggesting that both the $\mathrm{X}$ and the Y LGN cells are heavily modulated by mGluR5 in the cat. Also, in the somatosensory cortex of the rat, it has been reported that mGluR5 is densest within the primary thalamic input zones, the cortical barrels in layer IV, particularly during the neonatal period when barrels form. ${ }^{28,55}$ In mGluR5 knockout mice, the barrels fail to form. In adult primate V1, however, the picture is somewhat different. The highest density of mGluR5 is actually concentrated outside of layer IVC (IV), especially in the superficial layers. The density of mGluR5 in V1 (Figures 2 and 3) does not directly reflect the density of LGN input from any of the LGN pathways with the possible exception that layers I and IVA (IIIB $\beta$ ) stand out and are recipients of some K axons. ${ }^{56}$ The mGluR5 in layer III (IIIB $\alpha$ ) axons does not, however, identify the $\mathrm{CO}$ blob zones.

This result is presumably because the majority of this protein lies in dendrites, not axons. This V1 pattern suggests that mGluR5 is utilized in a variety of ways that are not necessarily directly linked to the LGN pathways in V1, at least in the adult primate. This finding makes sense, given that mGluR5 receptors modulate the expression of glutamate and would not be expected to dominate in zones carrying the main message from the thalamus. It is, however, possible that mGluR5 could show a pattern that more closely resembles LGN input earlier in development, since mGluR5 does appear to be developmentally regulated in rats and cats and shows changes following visual deprivation in cats. ${ }^{21,28,30}$

The observation that mGluR5 exists within fibers (presumably axons) within the white matter of V1 has not 
been reported before. Nevertheless, within the visual system (at the LM level), mGluR5 has been reported within the fibers of the optic tract in several species. ${ }^{27}$ mGluR5 positive axons within the white matter below V1 also would be expected, given that all $\mathrm{K}$ axons in our study showed evidence of mGluR5 within their terminals at the EM level. Additionally, there have been other reports of mGluR5 in vivo in excitatory axons. ${ }^{57}$ mGluR5 also has been observed within astrocytes by several groups in multiple areas of the nervous system, including the cerebral cortex. ${ }^{27,58-60}$

We did not systematically examine for mGluR5-positive astrocytes in the gray matter at the LM level, given the difficulty in discerning them in the densely stained neuropil. No immunostained astrocytes or other cell bodies were observed in our EM sections that were selectively taken from regions containing WGA-HRP labeled LGN axons. Nevertheless, within the superficial gray layers of the superior colliculus, mGluR5 immunopositive astrocytes clearly were identified in rat, cat, and ferret. ${ }^{27}$

At the EM level in our study, we found that the immunolocalization of mGluR5 was mostly confined to V1 dendrites, with the exception that all $\mathrm{K}$ axon terminals were labeled presynaptically. These findings are in general agreement with what others have found in different cortical regions in other species. Most investigators have reported that mGluR5 is localized perisynaptically within cortical dendrites, ${ }^{58,60-65}$ although no previous EM study specifically focused on the visual cortex in primates. Some, but not all, investigators also have reported the presence of mGluR5 within axon terminals. ${ }^{60,65}$ As reported by others, ${ }^{61}$ we rarely saw immunolabel within synapses themselves but, typically, found silver-enhanced gold particles within the cytoplasm or in a perisynaptic position. The consistency with which this pattern of localization has been seen with antibodies to mGluR $5^{61}$ suggests that it does not reflect some technical artifact. The position of this receptor relative to the synapse could explain the need for high-frequency stimulation to activate mGluR5 receptors at least in slice preparations. ${ }^{66,67}$ This result would also fit with the strong association structurally and functionally between the N-methyl-D-aspartate receptor and mGluR5. ${ }^{68}$

\section{Functional implications}

Within the primate visual system, the M, P, and K pathways have been proposed to play distinct roles. ${ }^{4,769-71}$ Classically, the M pathway has been proposed to be important in the processing of motion information and the $\mathrm{P}$ pathway in processing form and color information..$^{70}$ The role of the K pathway or pathways has been debated, and a number of possible roles have been proposed, all of them based upon heterogeneous physiological responses of K cells in the LGN. ${ }^{2,4,17,56,72}$ Current evidence suggests a more complex picture arguing that there may be at least eight or ten parallel geniculocortical pathways that perform different functions; see Casagrande and $\mathrm{Xu}^{4}$ for review. Our data on the distribution of mGluR5 in relation to the LGN pathways support the latter view. Our LM data suggest that mGluR5 is present at much lower levels only within the upper one-third of layer IVC (IV) and layer IVB (IIIC) of V1. Connectional and physiological data argue that this upper tier of layer IVC (IV) may receive input from a specialized population of $\mathrm{M}$ axons that send information indirectly (possibly even directly) via layer IVB (IIIC) to the middle temporal (MT) visual area for rapid analysis of visual motion. ${ }^{4,47,73}$ Our EM data indicate that this population of $\mathrm{M}$ axons may not be modulated by mGluR5, since the largest LGN axon terminals never showed evidence of mGluR5 either pre- or postsynaptically.

Additionally, in preliminary studies we have shown that the inhibitory mGluR $2 / 3$ protein is completely absent from all of layer IVC (IV) of V1 in several primate species, including the macaque and the bush baby (Otolemur garnettii) ${ }^{74}$ supporting the view that at least some $\mathrm{M}$ axons are not modulated by mGluRs.

Regarding the remainder of layer IVC (IV), connectional data indicate that the middle third of layer IVC (IV) receives input from both LGN M and P axons and the bottom one-third only from LGN P axons. ${ }^{75,76}$ Cells within these two subdivisions of layer IVC (IV) send their axons to upper cortical layer III (IIIB $\alpha$ ) and layer IVA (IIIB $\beta)$, which, based upon final output to V2, appear to be concerned with form and color analysis. ${ }^{4,76}$ In the present study, we found that the axon terminals in IVC (IV) with a smaller average size tended to synapse with dendrites containing mGluR5 about one-third of the time. These axon terminals may represent $\mathrm{P}$ axons, or $\mathrm{P}$ axons along with the subpopulation of $\mathrm{M}$ axons that supplies input to the upper cortical layers concerned with the analysis of object properties.

mGluR5 relates in a complex way to the $\mathrm{K}$ pathway, since all $\mathrm{K}$ axons contain the receptor presynaptically, but only $30 \%$ of these $\mathrm{K}$ axons contact dendrites that also contain the receptor. This means that, although glutamate in all $\mathrm{K}$ axons that terminate in the $\mathrm{CO}$ blobs may be modulated by mGluR5 autoreceptors, there will be further selective processing based upon the presence or absence of postsynaptic mGluR5 as well as other glutamate receptors. Although we do not have EM evidence for mGluR5 in $\mathrm{K}$ axons in the other laminar 
targets of these axons (IVA [IIIB $\beta$ ] and I), we did see LM evidence of mGluR5-labeled axons in layer I and layer II that showed very dense mGluR5 neuropil label. In layer IVA (IIIB $\beta$ ), which gets input from $\mathrm{K}$ axons carrying yellow/blue signals, ${ }^{77}$ however, we did not see mGluR5-labeled axons, even though this layer is very densely labeled for this protein. This picture fits with other evidence, indicating that the $\mathrm{K}$ pathway is not a single pathway but may contain several functionally distinct pathways. ${ }^{4,72}$

What sort of impact can mGluR5 have on visual information processing? In the visual cortex (area 17) of the cat, Reid and Daw ${ }^{20}$ found different effects in their efforts to activate mGluRs. Iontophoresing the nonspecific mGluR agonist 1S, 3R-aminocyclopentane-1,3 dicarboxylic acid (ACPD) into different visual cortical layers had different effects. They found that in the upper cortical layers (II and III), there was a significant decrease in both spontaneous and visually evoked responses; whereas, in cat layer IV (the IVC equivalent in primates), the effects were mixed, but the main effect was a small decrease in the evoked response. Finally, in the lower layers (V and VI), spontaneous activity increased but evoked responses were reduced. Reid and $\mathrm{Daw}^{20}$ argue that the reduction in evoked activity might reflect an impact on presynaptic receptors while the change in the spontaneous activity could reflect an impact on postsynaptic receptors.

Alternatively, the differences could reflect the impact of ACPD on different classes of mGluRs or some combination of them. In rat visual cortical slices, Sladeczek et $\mathrm{al}^{22}$ also reported evidence of presynaptic inhibitory effects using ACPD. Again, because of ACPD's nonspecific effects, it is not possible to relate these results directly to the specific function of mGluR5 receptors. This is particularly so given that in other areas of the nervous system, such as the thalamic reticular nucleus, the use of more specific mGluR agonists showed that activation of class II mGluRs resulted in glutamatergic inhibitory effects while the activation of class I mGluRs (ie, mGluR1 and mGluR5) resulted in glutamatergic excitation. ${ }^{78}$ In the LGN, results suggest that the activation of both group I and group II mGluRs suppress retinogeniculate transmission, at least in mice. ${ }^{79}$

Most studies examining the specific effects of mGluR5 have focused at the cell biological level, not the systems level, and often do not distinguish between the effects of mGluR5 and its close relative, mGluR $1 .{ }^{80}$ These studies have reported mainly, but not exclusively, facilitatory effects of activating these receptors together. ${ }^{26,81}$ Nevertheless, where the effects of these receptors have been directly compared, it is generally agreed that they have unique effects. ${ }^{25,82,83}$ Also, mGluR1 and mGluR5 are both coupled to inositol triphosphate/calcium signal transduction mechanisms. ${ }^{26,59,84}$

Single-cell recordings of calcium responses indicate that glutamate evokes nonoscillatory calcium increases in mGluR1-expressing cells and an oscillatory increase in calcium in mGluR5-expressing cells. ${ }^{85}$ These differences have been explained based upon a single amino acid substitution (aspartate for threonine) in mGluR5. ${ }^{86}$ Protein kinase $\mathrm{C}$ phosphorylation of the threonine of mGluR5 is responsible for inducing calcium oscillations. ${ }^{31}$ In the lamprey spinal cord, these oscillations in calcium, which are correlated with increases in the release of glutamate and depend upon the presynaptic mGluR class I receptors (probably mGluR5), are necessary for the maintenance of locomotion. ${ }^{31}$

In light of these studies, it is of particular interest that slow oscillatory patterns have been recorded uniquely within the $\mathrm{K}$ visual pathway at the level of the LGN in marmosets $^{33}$ and not found among $\mathrm{P}$ and $\mathrm{M}$ cells. One would want to know then if blocking mGluR5 receptors would alter reported oscillatory behavior of cells in V1. ${ }^{32}$ If so, this would hint that the K pathway plays an important role in controlling such oscillations in V1, assuming that the effects were presynaptic. Since highly specific agonists are now available for the different mGluRs, experiments of this sort should now be possible. Using these tools, it would be useful to repeat some of the earlier experiments done in cat, limiting the iontophoretic application to specific cortical layers to see how such applications affect the basic cortical receptive field properties of cells that receive direct input from M, P, and K LGN axons. Such studies will be necessary before we can construct reasonable hypotheses about the function of mGluR5 or other mGluRs in primary visual cortex.

\section{Acknowledgments}

We are especially grateful to Mary Feurtado for her excellent assistance with animal care and anesthesia and to Dr Gyula Sáry for expert assistance in surgery. We are also grateful to Mariesol Rodriguez, Markeil Lewis, Eesha Singh, Moses Koo, and Jay Patel for help with histology and to Phillip Sparks for editing assistance. We would also like to thank Drs Ford Ebner, Jennifer Ichida, Xiangmin $\mathrm{Xu}$, and David Royal for helpful comments on previous versions of this manuscript. This research was supported by National Institutes of Health grants EY001778 (VAC) and National Institutes of Health Core grants EY08126, HD15052. 


\section{Disclosure}

The authors report no conflicts of interest in this work.

\section{References}

1. Sherman SM, Guillery RW. Functional Connections of Cortical Areas: A New View from the Thalamus. Cambridge, MA: MIT Press; 2013.

2. Casagrande VA. A third parallel visual pathway to primate area V1. Trends Neurosci. 1994;17(7):305-310.

3. Casagrande VA, Kaas JH. The afferant, intrinsic, and efferent connections of primary visual cortex in primates. In: Peters A, Rockland KS, editors. Primary Visual Cortex of Primates. New York: Plenum; 1994;10:201-259.

4. Casagrande VA, Xu X. Parallel visual pathways: a comparative perspective. In: Chalupa LM, Werner JS, editors. The Visual Neurosciences. Cambridge, MA: MIT Press; 2004:494-506.

5. Brodmann K. Vergleichende lokalisationslehre der grosshirnrinde in ihren prinzipien dargestellt auf Grund des Zellenbaues. Leipzig: JA Barth; 1909.

6. Hässler R. Comparative anatomy of the central visual systems in day-and night-active primates. Evolution of the Forebrain. New York: Plenum Press; 1967:419-434.

7. Casagrande VA, Ichida JM. Processing in the lateral geniculate nucleus (LGN). In: Levin LA, Nilsson SFE, Ver Hoeve J, Wu SM, editors. Adler's Physiology of the Eye. 11th ed. Philadelphia, PA: Saunders Elsevier; 2011:574-585.

8. Shostak Y, Ding Y, Casagrande VA. Neurochemical comparison of synaptic arrangements of parvocellular, magnocellular, and koniocellular geniculate pathways in owl monkey (Aotus trivirgatus) visual cortex. J Comp Neurol. 2003;456(1):12-28.

9. Ding Y, Casagrande VA. Synaptic and neurochemical characterization of parallel pathways to the cytochrome oxidase blobs of primate visual cortex. J Comp Neurol. 1998;391(4):429-443.

10. McCormick DA, Huguenard JR. A model of the electrophysiological properties of thalamocortical relay neurons. J Neurophysiol. 1992;68(4): 1384-1400.

11. Morrison JH, Hof PR, Huntley GW. Neurochemical organization of the primate visual cortex. In: Bloom FE, Björklund A, Hökfelt T, editors. Handbook of Chemial Neuroanatomy: The Primate Nervous System, Part II. Amsterdam: Elsevier; 1998;14:299-430.

12. Shostak Y, Ding Y, Mavity-Hudson J, Casagrande VA. Cortical synaptic arrangements of the third visual pathway in three primate species: Macaca mulatta, Saimiri sciureus, and Aotus trivirgatus. J Neurosci. 2002;22(7):2885-2893.

13. Conn PJ, Battaglia G, Marino MJ, Nicoletti F. Metabotropic glutamate receptors in the basal ganglia motor circuit. Nat Rev Neurosci. 2005;6(10):787-798.

14. Platt SR. The role of glutamate in central nervous system health and disease - a review. Vet J. 2007;173(2):278-286.

15. Sherman SM. The thalamus is more than just a relay. Curr Opin Neurobiol. 2007;17(4):417-422.

16. Jones EG. Viewpoint: the core and matrix of thalamic organization. Neuroscience. 1998;85(2):331-345.

17. Hendry SH, Reid RC. The koniocellular pathway in primate vision. Annu Rev Neurosci. 2000;23:127-153.

18. Baskys A. Metabotropic Glutamate Receptors. Austin, TX: RG Landes Company; 1994.

19. Kato N. Long-term depression requiring tACPD-receptor activation and NMDA-receptor blockade. Brain Res. 1994;665(1):158-160.

20. Reid SN, Daw NW. Activation of metabotropic glutamate receptors has different effects in different layers of cat visual cortex. Vis Neurosci. 1997;14(1):83-88.

21. Reid SN, Romano C, Hughes T, Daw NW. Immunohistochemical study of two phosphoinositide-linked metabotropic glutamate receptors (mGluR1 alpha and mGluR5) in the cat visual cortex before, during, and after the peak of the critical period for eye-specific connections. J Comp Neurol. 1995;355(3):470-477.
22. Sladeczek F, Momiyama A, Takahashi T. Presynaptic inhibitory action of a metabotropic glutamate receptor agonist on excitatory transmission in visual cortical neurons. Proc Biol Sci. 1993;253(1338):297-303.

23. Wang Z, McCormick DA. Control of firing mode of corticotectal and corticopontine layer V burst-generating neurons by norepinephrine, acetylcholine, and 1S,3R-ACPD. J Neurosci. 1993;13(5): 2199-2216.

24. Conn PJ, Pin JP. Pharmacology and functions of metabotropic glutamate receptors. Annu Rev Pharmacol Toxicol. 1997;37:205-237.

25. Nakanishi S. Metabotropic glutamate receptors: synaptic transmission, modulation, and plasticity. Neuron. 1994;13(5):1031-1037.

26. Pin JP, Duvoisin R. The metabotropic glutamate receptors: structure and functions. Neuropharmacology. 1995;34(1):1-26.

27. Cirone J, Sharp C, Jeffery G, Salt TE. Distribution of metabotropic glutamate receptors in the superior colliculus of the adult rat, ferret and cat. Neuroscience. 2002;109(4):779-786.

28. Blue ME, Martin LJ, Brennan EM, Johnston MV. Ontogeny of nonNMDA glutamate receptors in rat barrel field cortex: I. Metabotropic receptors. J Comp Neurol. 1997;386(1):16-28.

29. Wijetunge LS, Till SM, Gillingwater TH, Ingham CA, Kind PC. mGluR5 regulates glutamate-dependent development of the mouse somatosensory cortex. J Neurosci. 2008;28(49):13028-13037.

30. Daw NW, Reid SN, Beaver CJ. Development and function of metabotropic glutamate receptors in cat visual cortex. $J$ Neurobiol. 1999;41(1):102-107.

31. Takahashi M, Alford S. The requirement of presynaptic metabotropic glutamate receptors for the maintenance of locomotion. J Neurosci. 2002;22(9):3692-3699.

32. Engel AK, Fries P, Singer W. Dynamic predictions: oscillations and synchrony in top-down processing. Nat Rev Neurosci. 2001;2(10): 704-716.

33. Cheong SK, Tailby C, Martin PR, Levitt JB, Solomon SG. Slow intrinsic rhythm in the koniocellular visual pathway. Proc Natl Acad Sci U SA. 2011;108(35):14659-14663.

34. Harvey BD, Siok CJ, Kiss T, et al. Neurophysiological signals as potential translatable biomarkers for modulation of metabotropic glutamate 5 receptors. Neuropharmacology. 2013;75:19-30.

35. Ribeiro FM, Pires RG, Ferguson SS. Huntington's disease and Group I metabotropic glutamate receptors. Mol Neurobiol. 2011;43(1):1-11.

36. Bear MF, Huber KM, Warren ST. The mGluR theory of fragile X mental retardation. Trends Neurosci. 2004;27(7):370-377.

37. Sokol D, Maloney B, Long JM, Ray B, Lahiri D. Autism, Alzheimer disease, and fragile X: APP, FMRP, and mGluR5 are molecular links. Neurology. 2011;76(15):1344-1352.

38. Devon RS, Anderson S, Teague PW, et al. The genomic organisation of the metabotropic glutamate receptor subtype 5 gene, and its association with schizophrenia. Mol Psychiatry. 2001;6(3):311-314.

39. Elia J, Gai X, Xie HM, et al. Rare structural variants found in attention-deficit hyperactivity disorder are preferentially associated with neurodevelopmental genes. Mol Psychiatry. 2009;15(6):637-646.

40. Silverman JL, Tolu SS, Barkan CL, Crawley JN. Repetitive selfgrooming behavior in the BTBR mouse model of autism is blocked by the mGluR5 antagonist MPEP. Neuropsychopharmacology. 2009;35(4): 976-989.

41. Ding Y, Casagrande VA. The distribution and morphology of LGN K pathway axons within the layers and CO blobs of owl monkey V1. Vis Neurosci. 1997;14(4):691-704.

42. Lachica EA, Beck PD, Casagrande VA. Intrinsic connections of layer III of striate cortex in squirrel monkey and bush baby: correlations with patterns of cytochrome oxidase. J Comp Neurol. 1993;329(2): 163-187.

43. Lachica EA, Casagrande VA. Direct W-like geniculate projections to the cytochrome oxidase (CO) blobs in primate visual cortex: axon morphology. J Comp Neurol. 1992;319(1):141-158.

44. Horn AK, Hoffmann KP. Combined GABA-immunocytochemistry and TMB-HRP histochemistry of pretectal nuclei projecting to the inferior olive in rats, cats and monkeys. Brain Res. 1987;409(1):133-138. 
45. Mesulam MM. Tetramethyl benzidine for horseradish peroxidase neurohistochemistry: a non-carcinogenic blue reaction product with superior sensitivity for visualizing neural afferents and efferents. J Histochem Cytochem. 1978;26(2):106-117.

46. Wong-Riley M. Changes in the visual system of monocularly sutured or enucleated cats demonstrable with cytochrome oxidase histochemistry. Brain Res. 1979;171(1):11-28.

47. Boyd JD, Matsubara JA. Laminar and columnar patterns of geniculocortical projections in the cat: relationship to cytochrome oxidase. J Comp Neurol. 1996;365(4):659-682.

48. Hanson JE, Smith Y. Group I metabotropic glutamate receptors at GABAergic synapses in monkeys. J Neurosci. 1999;19(15): 6488-6496.

49. Livingstone MS, Hubel DH. Thalamic inputs to cytochrome oxidaserich regions in monkey visual cortex. Proc Natl Acad Sci U S A. 1982;79(19):6098-6101.

50. Fitzpatrick D, Itoh K, Diamond IT. The laminar organization of the lateral geniculate body and the striate cortex in the squirrel monkey (Saimiri sciureus). J Neurosci. 1983;3(4):673-702.

51. Freund TF, Buzsáki G, Prohaska OJ, Leon A, Somogyi P. Simultaneous recording of local electrical activity, partial oxygen tension and temperature in the rat hippocampus with a chamber-type microelectrode. Effects of anaesthesia, ischemia and epilepsy. Neuroscience. 1989;28(3): 539-549.

52. Winfield DA, Rivera-Dominguez M, Powell TP. The termination of geniculocortical fibres in area 17 of the visual cortex in the macaque monkey. Brain Res. 1982;231(1):19-32.

53. Peters A, Payne BR. Numerical relationships between geniculocortical afferents and pyramidal cell modules in cat primary visual cortex. Cereb Cortex. 1993;3(1):69-78.

54. Peters A, Payne BR, Budd J. A numerical analysis of the geniculocortical input to striate cortex in the monkey. Cereb Cortex. 1994;4(3):215-229.

55. Ballester-Rosado CJ, Albright MJ, Wu CS, et al. mGluR5 in cortical excitatory neurons exerts both cell-autonomous and -nonautonomous influences on cortical somatosensory circuit formation. J Neurosci. 2010;30(50):16896-16909.

56. Casagrande VA, Yazar F, Jones KD, Ding Y. The morphology of the koniocellular axon pathway in the macaque monkey. Cereb Cortex. 2007;17(10):2334-2345.

57. Fazal A, Parker F, Palmer AM, Croucher MJ. Characterisation of the actions of group I metabotropic glutamate receptor subtype selective ligands on excitatory amino acid release and sodium-dependent re-uptake in rat cerebrocortical minislices. J Neurochem. 2003;86(6):1346-1358.

58. Muñoz A, Liu XB, Jones EG. Development of metabotropic glutamate receptors from trigeminal nuclei to barrel cortex in postnatal mouse. J Comp Neurol. 1999;409(4):549-566.

59. Niswender CM, Conn PJ. Metabotropic glutamate receptors: physiology, pharmacology, and disease. Annu Rev Pharmacol Toxicol. 2010;50:295-322.

60. Romano C, Sesma MA, McDonald CT, O’Malley K, Van den Pol AN, Olney JW. Distribution of metabotropic glutamate receptor mGluR5 immunoreactivity in rat brain. J Comp Neurol. 1995;355(3):455-469.

61. López-Bendito G1, Shigemoto R, Fairén A, Luján R. Differential distribution of group I metabotropic glutamate receptors during rat cortical development. Cereb Cortex. 2002;12(6):625-638.

62. Lujan R, Nusser Z, Roberts JD, Shigemoto R, Somogyi P. Perisynaptic location of metabotropic glutamate receptors mGluR 1 and mGluR5 on dendrites and dendritic spines in the rat hippocampus. Eur J Neurosci. 1996;8(7):1488-1500.

63. Martin LJ, Blackstone CD, Huganir RL, Price DL. Cellular localization of a metabotropic glutamate receptor in rat brain. Neuron. 1992;9(2): 259-270.
64. Shigemoto R, Nomura S, Ohishi H, Sugihara H, Nakanishi S, Mizuno N. Immunohistochemical localization of a metabotropic glutamate receptor, mGluR5, in the rat brain. Neurosci Lett. 1993;163(1):53-57.

65. Muly EC, Maddox M, Smith Y. Distribution of mGluR $1 \alpha$ and mGluR5 immunolabeling in primate prefrontal cortex. J Comp Neurol. 2003;467(4):521-535.

66. Charpak S, Gähwiler BH. Glutamate mediates a slow synaptic response in hippocampal slice cultures. Proc Biol Sci. 1991;243(1308): 221-226.

67. McCormick DA, von Krosigk M. Corticothalamic activation modulates thalamic firing through glutamate "metabotropic" receptors. Proc Natl Acad Sci US A. 1992;89(7):2774-2778.

68. Alagarsamy S, Rouse ST, Junge C, et al. NMDA-induced phosphorylation and regulation of mGluR5. Pharmacol Biochem Behav. 2002;73(2):299-306.

69. Casagrande VA, Norton TT. The lateral geniculate nucleus: A review of its physiology and function. In: Leventhal AG, editor. Vision and Visual Dysfunction, Vol 4: The Neural Basis of Visual Function. London: MacMillan Press; 1991;41-84.

70. Livingstone M, Hubel D. Segregation of form, color, movement, and depth: anatomy, physiology, and perception. Science. 1988;240(4853): 740-749.

71. Merigan WH, Maunsell JH. How parallel are the primate visual pathways? Annu Rev Neurosci. 1993;16:369-402.

72. Xu X, Ichida JM, Allison JD, Boyd JD, Bonds AB, Casagrande VA. A comparison of koniocellular, magnocellular and parvocellular receptive field properties in the lateral geniculate nucleus of the owl monkey (Aotus trivirgatus). J Physiol. 2001;531(Pt 1):203-218.

73. Blasdel GG, Lund JS. Termination of afferent axons in macaque striate cortex. J Neurosci. 1983;3(7):1389-1413.

74. Koo M, Wenger A, Singh E, Mavity-Hudson JA, Marion RT, Casagrande VA. Driving and modulatory pathways illuminated by immunostaining in primate cortex. Society for Neuroscience. 2013:Program No 638.622/DD617 (abs)

75. Boyd JD, Mavity-Hudson JA, Casagrande VA. The connections of layer 4 subdivisions in the primary visual cortex (V1) of the owl monkey. Cereb Cortex. 2000;10(7):644-662.

76. Yabuta NH, Callaway EM. Functional streams and local connections of layer $4 \mathrm{C}$ neurons in primary visual cortex of the macaque monkey. J Neurosci. 1998;18(22):9489-9499.

77. Chatterjee S, Callaway EM. Parallel colour-opponent pathways to primary visual cortex. Nature. 2003;426(6967):668-671.

78. Cox CL, Sherman SM. Glutamate inhibits thalamic reticular neurons. J Neurosci. 1999;19(15):6694-6699.

79. Lam YW, Sherman SM. Activation of both Group I and Group II metabotropic glutamatergic receptors suppress retinogeniculate transmission. Neuroscience. 2013;242:78-84.

80. Hermans E, Challiss RA. Structural, signalling and regulatory properties of the group I metabotropic glutamate receptors: prototypic family $\mathrm{C}$ G-protein-coupled receptors. Biochem J. 2001;359(Pt 3):465-484.

81. Schoepp DD, Conn PJ. Metabotropic glutamate receptors in brain function and pathology. Trends Pharmacol Sci. 1993;14(1):13-20.

82. Nakanishi S. Molecular diversity of glutamate receptors and implications for brain function. Science. 1992;258(5082):597-603.

83. Nakanishi S. The molecular diversity of glutamate receptors. Prog Clin Biol Res. 1994;390:85-98.

84. Conn PJ, Patel J, editors. The Metabotropic Glutamate Receptors. Totowa, NJ: Humana; 1994

85. Nakanishi S, Nakajima Y, Masu M, et al. Glutamate receptors: brain function and signal transduction. Brain Res Brain Res Rev. 1998;26(2-3):230-235.

86. Kawabata S, Tsutsumi R, Kohara A, Yamaguchi T, Nakanishi S, Okada M. Control of calcium oscillations by phosphorylation of metabotropic glutamate receptors. Nature. 1996;383(6595):89-92. 
Eye and Brain

\section{Publish your work in this journal}

Eye and Brain is an international, peer-reviewed, open access journal focusing on clinical and experimental research in the field of neuro-ophthalmology. All aspects of patient care are addressed within the journal as well as basic research. Papers covering original research, basic science, clinical and epidemiological studies, reviews and and extended reports are welcome. The manuscript management system is completely online and includes a very quick and fair peer-review system, which is all easy to use. Visit http://www.dovepress.com/ testimonials.php to read real quotes from published authors.

Dovepress 